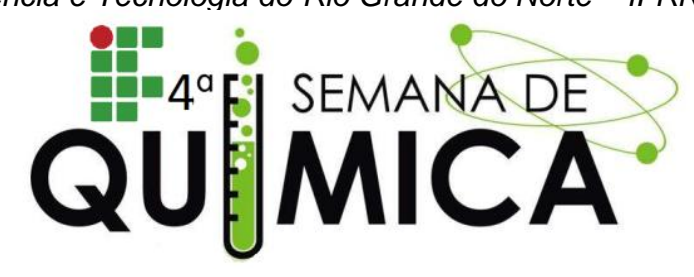

\title{
ÓLEO ESSENCIAL DO ILLICIUM VERUM (ANIS-ESTRELADO): EXTRAÇÃO E APLICAÇÃO NA PRODUÇÃO DE INCENSO
}

BARBOSA, J. V. O. (IFRN); SOUZA, D. S. (ORIENTADORA/IFRN)

Palavras-Chave: Óleo Essencial, Extração, Produção De Incenso.

\section{INTRODUÇÃO}

A extração de óleos essenciais é um processo físico-químico bastante útil quando se quer obter aromas naturais de plantas, folhas, frutos, ou qualquer espécime que possuir odor característico.

O Anis-estrelado (Illicium Verum) é uma planta nativa da Ásia e Egito e é utilizada desde a antiguidade. Trata-se de uma planta arbórea que pode variar de 2,5 a 4 metros de altura. 0 fruto é marrom pedunculado e possui oito carpelos e a semente é amarelada. (NEGRAES, 2003 apud FREIRE, 2008).

Os incensos são cotidianamente utilizados como aromatizadores de ambientes e, em alguns casos, como terapêuticos medicinais. Este trabalho visa demonstrar como o óleo essencial do Anis-estrelado pode ser aplicado na produção de incensos a partir da extração por destilação de arraste a vapor.

\section{METODOLOGIA}

\section{Materiais e reagentes:}

Frutos e sementes do Anis-estrelado, balão de destilação, condensador, manta aquecedora, suporte universal, mangueiras, balança analítica, almofariz, pistilo, erlenmeyer, béquer, termômetro, rolhas, água de destilada, barrilete, agitador magnético, cola, álcool etílico, palitos de bambu, pó de madeira, nitrato de potássio, enxofre, nitrato de sódio, amido de milho, carvão vegetal, papel filme.
Inicialmente, foi feita a coleta do material para a extração e o mesmo levado até o laboratório de físico-química do IFRN campus Nova Cruz.

Após a lavagem dos frutos e sementes do Anis, foi feita o maceramento e em seguida a pesagem de 30,5 gramas.

O material foi então misturado a 200 $\mathrm{mL}$ de água destilada e colocado na manta aquecedora conectada ao sistema de destilação (vide figura 01).

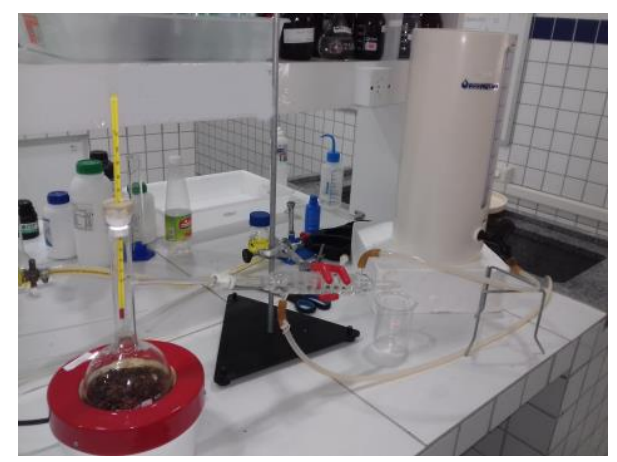

Figura 1 - Sistema de destilação por arraste a vapor. Fonte: própria.

Após a extração, o óleo foi aplicado na fabricação da massa para o incenso junto com: 7,5 gramas nitrato de potássio, 1,0 grama de enxofre, 1,5 gramas de nitrato de sódio, 5 gramas de amido de milho, $2 \mathrm{~mL}$ de álcool etílico, 20 gramas de carvão vegetal, 20 gramas de pó de madeira, obtendo assim uma massa homogênea e consistente para a produção do incenso.

\section{Procedimento experimental:}




\section{RESULTADOS E DISCUSSÕES}

Após cerca de duas horas de processo conseguiu-se extrair cerca de $125 \mathrm{~mL}$ de óleo essencial que representa $62,5 \%$ de rendimento, considerando a massa pesada anteriormente.

A massa produzida foi impregnada em palitos de bambu e secada por 48 horas (vide figura 02) rendendo 5 incensos. A queima de um incenso de cerca de $15 \mathrm{~cm}$ dura em torno de 10 minutos, mas apenas $10 \mathrm{~cm}$ é impregnado com a massa para incenso ou seja (1 cm por minuto). (Vide figura 03).

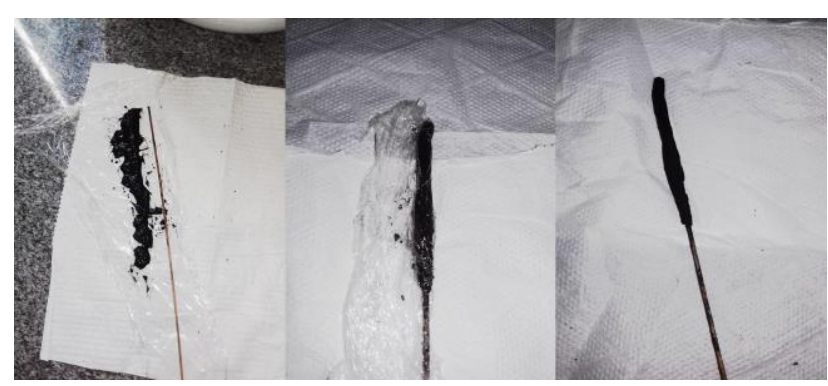

Figura 2 - Palito de bambu impregnado com massa para incenso. Fonte: própria.

O aroma agradável, característico no anis-estrelado, foi obtido com sucesso após a queima do incenso, mostrando que o mesmo pode ser empregado para este fim.

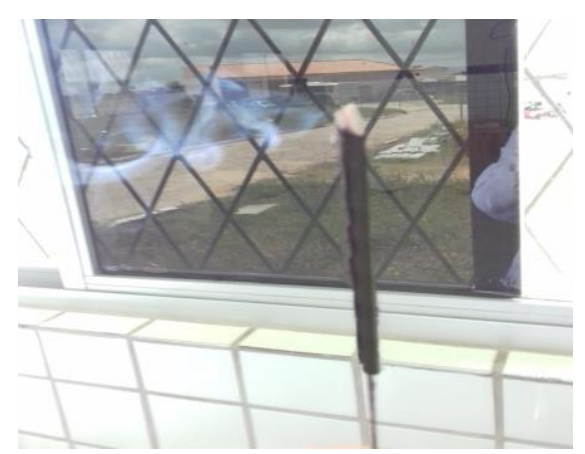

Figura 3 - Resultando final, queima do incenso. Fonte: própria.

\section{CONCLUSÃO}

Após a extração do óleo foi possível a aplicação do mesmo na produção de incensos que serão úteis na aromatização de ambientes, com efeitos terapêuticos, ou mesmo repelentes contra insetos (em trabalhos futuros). A aromatização foi bastante eficaz tornando o ambiente com aroma típico da planta utilizada. A massa rendeu entre cinco e seis incensos, tornando assim sua produção viável, uma vez que é obtida quase totalmente de forma artesanal.

\section{REFERÊNCIAS}

${ }^{1}$ FREIRE, J. M. Óleos essenciais de canela, manjerona e anis-estrelado: caracterização química e atividade biológica sobre Staphylococcus aureus, Escherichia coli, Aspergillus flavus e Aspergillus parasiticus. Minas Gerais: UFLA, 2008. Disponível em < http://repositorio.ufla.br/handle/1/1976> acesso em 20/07/2016.

${ }^{2}$ LIMA, R. K. Et al. Composição dos Óleos Essenciais de Anis-estrelado Illicium verum L. e de Capim-limão Cymbopogon citratus (DC.) Stapf: Avaliação do Efeito Repelente sobre Brevicoryne brassicae (L.) (Hemiptera: Aphididae). Minas Gerais: UFLA, 2008. Disponível em < https://www.bioassay.org.br/bioassay/article/v iew/56> acesso em 19/07/2016.

${ }^{3}$ LASZLO AROMATERAPIA. Extração de óleos essenciais. São Paulo: USJT, 2001. Disponível em

<laszlo.ind.br/admin/artigos/arquivos/extracao oe.pdf> acesso em 19/07/2016.

${ }^{4}$ TRANCOSO, M. D. Projeto Óleos Essenciais: extração, importância e aplicações no cotidiano. Rio de Janeiro: CBNB, 2013. Disponível em <http://www.abq.org.br/cbq/2013/trabalhos/1 4/2780-17038.html> acesso em 20/07/2016.

${ }^{5}$ DIAS, Diogo Lopes. "Destilação por arraste de vapor"; Brasil Escola. Disponível em <http://brasilescola.uol.com.br/quimica/destila cao-por-arraste-vapor.htm>. Acesso em 20 de julho de 2016. 